\title{
DIET AND FEEDING BEHAVIOR OF THE SOLPUGID, EREMOBATES PALPISETULOSUS (SOLPUGIDA: EREMOBATIDAE)
}

\author{
By FRED Punzo \\ Dept. of Biology, Box $5 \mathrm{~F}$ \\ University of Tampa \\ Tampa, FL 33606
}

\begin{abstract}
Eremobates palipsetulosus is a generalist predator which preys upon a wide variety of arthropods and seems to prefer smaller, soft-bodied prey items. Spiders as well as orthopteran, lepidopteran and coleopteran insects comprise $76 \%$ of the total diet. When a prey item is encountered, the palpi are used to pull the prey toward the chelicerae. The prey is then grasped in the chelicerae which are used to fragment and grind the prey tissues for subsequent ingestion. Increased hunger levels result in significantly faster ingestion time and higher capture rates. This is the first quantitative study on prey capture and feeding behavior for solpugids.
\end{abstract}

\section{INTRODUCTION}

Solpugids represent an important component of the arachnid fauna inhabiting desert regions worldwide (Muma, 1967; Cloudsley-Thompson, 1977). Although the predatory nature of these arachnids is well known (Bolwig, 1952; Muma, 1966; Wharton, 1987), no detailed analysis is available concerning the dietary preferences and feeding relationships of solpugids. Muma (1966) provided some general information on ingestive behavior, search and location of potential prey, and reactions toward prey items offered in the laboratory, but no data are available concerning actual prey items captured in the field.

In this study, I examined the following parameters associated with feeding in Eremobates palpisetulosus Fichter: (1) prey species captured in the field; (2) dietary preferences based on prey

Manuscript received 12 July 1993. 
size and hardness of prey cuticle; (3) percent capture success as a function of hunger level (food deprivation); and (4) the effect of hunger level and predator size on ingestion time.

\section{Materials AND Methods}

Eremobates palpisetulosus is a common inhabitant of the northern region of the Chihuahuan Desert (Muma, 1951). Adult males (18-23 mm, total body length), females (19-24 mm) and immatures $(<10 \mathrm{~mm})$ were collected while wandering the surface at night during May-August, 1991. Solpugids were collected within a $12-\mathrm{km}$ radius of Terlingua, Texas (Brewster Co.), which lies within the Big Bend Region of Trans Pecos Texas. Two consecutive years of higher-than-normal rainfall was most likely an important factor contributing to the high numbers of solpugids encountered during this period. A detailed description of the geology and vegetational zones of this region is given by Tinkam (1948). A helmet-mounted light with a red filter was used to locate and observe solpugids as they moved across the substrate. Each animal was captured and examined for identification according to Muma (1951) as well as for the presence of prey in the chelicerae. A total of 466 solpugids were observed, 92 of which (19.7\%) possessed a prey item. The prey from each solpugid was placed in alcohol for subsequent identification to order or family depending on the degree of digestion (Table 1).

Since adult females were encountered more frequently than males, subsequent laboratory studies were conducted on females. These solpugids were placed individually in plastic containers (20 $\times 15 \times 6 \mathrm{~cm}$ ), provided with water and fed on a diet of mealworm larvae (Tenebrio molitor) and crickets (Acheta domestica). These species were chosen because they are not found at the collection sites and therefore would minimize any choice bias as noted in confounding subsequent prey acceptability studies. Solpugids were maintained at $22^{\circ} \pm 1{ }^{\circ} \mathrm{C}$ and $70-80 \%$ relative humidity as described by Punzo (1993).

Twenty solpugids were selected at random for an analysis of dietary preferences as reflected by prey species actually captured and ingested by E. palpisetulosus. All prey species in these experiments were collected from the same location as the solpugids. The experimental protocol was identical to that described by Young 
(1989) and Punzo (1991) for lycosid spiders. Solpugids were deprived of food for one week prior to testing. Individual solpugids were placed in a clean plastic container $(15 \times 10 \times 5$ $\mathrm{cm}$ ) used as a test chamber. Prey organisms of different taxa and size classes were used (Table 2). An individual prey organism was placed in the center of the container with a solpugid and the status of the prey (rejected or captured and ingested) was recorded after $24 \mathrm{hr}$. Unconsumed material was removed after each test. Each prey species was offered to 20 different solpugids. In order to minimize any effect of experience, prey of the same species were never presented consecutively as suggested by Nentwig (1987). All feeding trials were recorded using a Cine- 8 high speed video camera (Visual Instrumentation Corp.) at 100 frames/sec. A Lafayette Super 8 Analyzer (Model 1026) was used for frame-by-frame analysis as described by Punzo (1989).

To determine the effects of hunger level on percent capture success (Table 3), 20 different solpugids were tested individually at each of four levels of food deprivation $(6,24,48$ and $72 \mathrm{hr}$ ) according to the method described by Punzo (1989). In order to standardize test trials, these experiments were conducted using a runway apparatus as described by Punzo (1989). The runway (15 $\times 8 \times 6 \mathrm{~cm})$ was constructed of clear plexiglass. The solpugid was placed in a holding chamber $(9 \times 10 \times 6 \mathrm{~cm})$ in a foreward-facing position at one end of the runway. The prey item to be tested (A. domestica) was placed in a compartment $(5 \times 8 \times 6 \mathrm{~cm})$ provided with a restraining door at the opposite end of the runway. Solpugids were allowed to habituate to the holding chamber for 30 min prior to the initiation of test trials. The degree of hunger (food deprivation) was defined as the time (hr) elapsed since the last feeding according to Dethier (1982). Before the start of each test trial, a cricket was placed in the prey compartment. A movable restraining door prevented the cricket from entering the runway. At the start of each trial, the restraining door was lifted manually and a gentle stream of compressed air was introduced through an intake valve leading to the back of the prey compartment. In response to the air flow, the cricket would immediately move directly into the runway and toward the solpugid positioned at the opposite end. The percent capture success was recorded for all trials. A capture attempt was considered to be successful if a solpugid firmly grasped a cricket in its chelicerae and began to 
Table 1. Prey items captured by Eremobates palpisetulosus during field observations ( $\mathrm{N}=92$ solpugids and prey items). Life cycle stage of prey: A (adult), $\mathrm{N}$ (nymph), I (immature), L (larva). Percentage of total prey is given in parentheses.

\section{Prey taxon}

Number of prey items

Arachnida (15.2)

Araneae

Lycosidae

Lycosa avida (A) $\quad 3$

Pardosa sternalis (A) 2

Undetermined (A) 9

Insecta

Coleoptera (15.2)

Carabidae (A) 5

Cicindelidae (A) 3

Scarabaeidae (A) 1

Tenebrionidae (A) $\quad 3$

Undetermined (A) 2

Dictyoptera (2.2)

Blattellidae (A) 2

Diptera (9.7)

Asilidae (A) 2

Muscidae (A) 2

Tabanidae (A) 1

Tipulidae (A) 1

Undetermined (A) 3

Heteroptera (7.7)

Lygaeidae (N) $\quad 1$

Miridae (A) 1

Pentatomidae (N) 1

Reduviidae (A) 2

Undetermined $(\mathrm{N}) \quad 2$ 
Table 1 (continued)

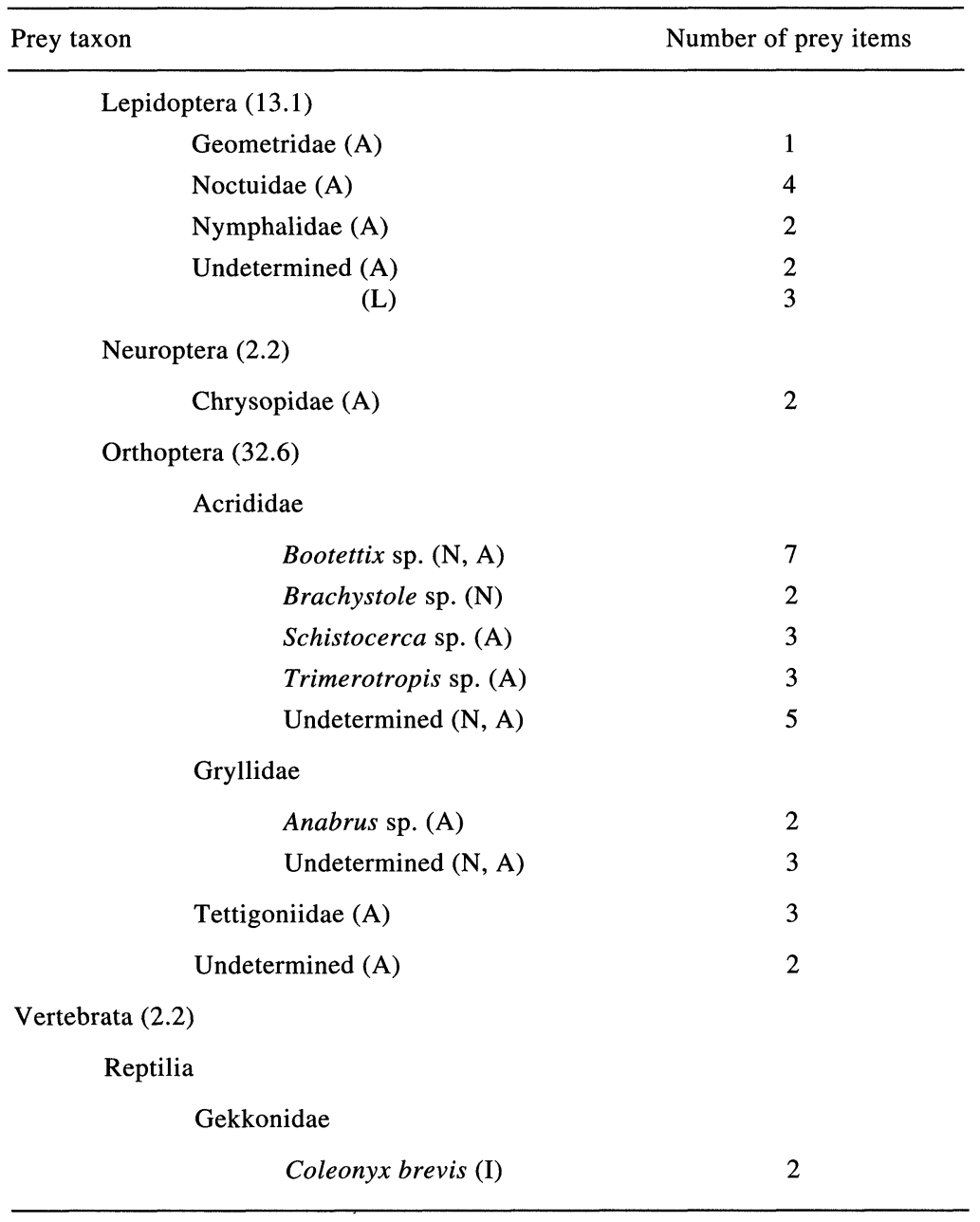


Table 2. Laboratory experiments on prey items captured and ingested by Eremobates palpisetulosus adult females. Life cycle stage of prey: A (adult), N (nymph), I (immature). All prey items were collected from the same locality as E. palpisetulosus. $\mathrm{N}=20$ for each prey species.

\begin{tabular}{|c|c|c|c|}
\hline Prey species & $\begin{array}{l}\text { Mean body } \\
\text { length of } \\
\text { prey }(\mathrm{mm})\end{array}$ & $\begin{array}{l}\text { Mean body } \\
\text { length of } \\
\text { predator }(\mathrm{mm})\end{array}$ & $\begin{array}{c}\text { Percentage } \\
\text { capture and } \\
\text { ingestion }\end{array}$ \\
\hline \multicolumn{4}{|l|}{ Araneae } \\
\hline \multicolumn{4}{|l|}{ Lycosidae } \\
\hline Lycosa avida (A) & 11.4 & 22.3 & 30 \\
\hline (I) & 6.2 & 22.1 & 65 \\
\hline \multicolumn{4}{|l|}{ Coleoptera } \\
\hline \multicolumn{4}{|l|}{ Carabidae } \\
\hline Calosoma scrutator (A) & 27.1 & 20.6 & 0 \\
\hline Cicindela punctulata (A) & 10.2 & 22.3 & 10 \\
\hline \multicolumn{4}{|l|}{ Meloidae } \\
\hline Lytta magister (A) & 12.3 & 22.2 & 5 \\
\hline \multicolumn{4}{|l|}{ Silphidae } \\
\hline Silpha sp. & 9.4 & 21.8 & 60 \\
\hline \multicolumn{4}{|l|}{ Tenebrionidae } \\
\hline Conibius gagates (A) & 6.7 & 19.2 & 25 \\
\hline \multicolumn{4}{|l|}{ Dictyoptera } \\
\hline \multicolumn{4}{|l|}{ Blattellidae } \\
\hline Blattella vaga $(\mathrm{N})$ & 9.4 & 22.4 & 85 \\
\hline (A) & 16.1 & 19.7 & 60 \\
\hline \multicolumn{4}{|l|}{ Hymenoptera } \\
\hline \multicolumn{4}{|l|}{ Formicidae } \\
\hline Pheidole sp. & 3.1 & 20.2 & 0 \\
\hline \multicolumn{4}{|l|}{ Mutillidae } \\
\hline Dasymutilla magnifica (A) & 13.7 & 22.4 & 0 \\
\hline \multicolumn{4}{|l|}{ Orthoptera } \\
\hline \multicolumn{4}{|l|}{ Acrididae } \\
\hline Bootettix argentatus $(\mathrm{A})$ & 19.1 & 22.2 & 30 \\
\hline Schistocerca vaga (A) & 23.4 & 21.7 & 0 \\
\hline$(\mathrm{N})$ & 7.6 & 21.1 & 70 \\
\hline \multicolumn{4}{|l|}{ Solpugida } \\
\hline E. palpisetulosus (A) & 20.8 & 21.6 & 15 \\
\hline (I) & 8.3 & 19.8 & 80 \\
\hline
\end{tabular}


Table 3. Percent capture success for Eremobates palpisetulosus adult females (mean body length: $21.4 \mathrm{~mm}$ ) as a function of food deprivation (in $\mathrm{hr}$ ). $\mathrm{N}=20$ solpugids for each deprivation level. Prey species: Acheta domestica (mean body length: $10.7 \mathrm{~mm}$ ).

\begin{tabular}{cc}
\hline Food deprivation (hr) & Percent capture success (\%) \\
\hline 6 & 10 \\
24 & 15 \\
48 & 35 \\
72 & 60 \\
\hline
\end{tabular}

ingest the prey. An attempt was considered a failure if the solpugid missed the cricket entirely or if it grasped the prey only momentarily before it escaped.

Experiments were also conducted to assess the effects of hunger and predator size on the amount of time required to ingest a single cricket weighing $0.25 \pm .05 \mathrm{~g}$. Two predator size classes (body length: $8.7-9.9 \mathrm{~mm}$; weight $0.6 \pm .03 \mathrm{~g}$; and $20.2-23.0 \mathrm{~mm} ; 1.5 \pm$ $.27 \mathrm{~g}$ ), each comprising 15 different solpugids, were deprived of food for $6,24,48$ or $72 \mathrm{hr}$ prior to testing. The amount of time (min) required for each solpugid to ingest the prey was recorded. Ingestion time was defined as the amount of time that elapsed between initial grasping of the prey and the discarding of undigested cuticular fragments (Punzo, 1989). Each solpugid was tested only once in order to minimize the effect of experience.

\section{Results AND Discussion}

Eremobates palpisetulosus captures a wide variety of prey (Table 1) and as such can be considered a generalist predator (Curio, 1976). Prey consisted of spiders, insects and lizards. Orthopteran insects comprised $32.6 \%$ of the total prey items, followed by spiders $(15.2 \%)$, Coleoptera $(15.2 \%)$, Lepidoptera (13.1\%), Diptera (9.7\%), Heteroptera (7.7\%), Neuroptera (2.2\%), Dictyoptera $(2.2 \%)$, and geckonid lizards $(2.2 \%)$. As a group, insects comprised $82.6 \%$ of the diet. Two solpugids were found holding the partially macerated bodies of the gecko, Coleonyx bre$v i s$, in their chelicerae. This nocturnal gecko is fairly common at this study area (Punzo, 1974) suggesting that E. palpisetulosus is 
capable of capturing and ingesting small vertebrates. Preying on lizards agrees with the observations of Banta and Marer (1972) who reported a solpugid, Galeodes sp., feeding on a hatchling lizard. It is interesting to note that arthropods with well known chemical defenses such as blister beetles (Meloidae), velvet ants (Mutillidae), ants (Formicidae), scorpions and centipedes, all of which are common in this area and mostly nocturnal during summer months (Punzo, 1989; Punzo and Huff, 1989), were not taken by these solpugids. Further evidence is provided by the laboratory experiments on prey acceptability (Table 2).

The results from the laboratory experiments on prey capture are shown in Table 2. These observations support the field observations. Smaller prey are captured and ingested with greater frequency than those whose body size closely approximates that of the solpugids. For example, the capture rate for blattellid nymphs is $85 \%$, but only $60 \%$ for the larger adults $(\mathrm{G}=11.9, \mathrm{p}<0.01$, Sokal and Rohlf, 1981). The capture rate for nymphs of Schistocerca vaga $(70 \%)$ is much higher than that for the adults $(0 \%)(\mathrm{G}=$ $19.7, \mathrm{p}<0.001)$. This is in contrast to results of similar experiments with spiders and scorpions, many of which frequently capture and ingest prey items significantly larger than themselves (Curio, 1976; Nentwig, 1987; Punzo, 1989, 1991). In addition, hard-bodied prey such as the carabid beetles, Calosoma scrutator and Cicindela punctulata, and the tenebrionid beetle, Conibius gagates, are captured with relatively low success $(0-25 \%)$. Well defended prey such as the blister beetle, Lytta magister, and the velvet ant, Dasymutilla magnifica, were never captured by these solpugids. Eremobates palpisetulosus exhibits a high capture rate for soft-bodied prey such as the silphid beetle, Silpha sp., immature lycosid spiders, blattellid roaches, and acridid nymphs $(60-85 \%)$. Note that immature conspecifics are also readily captured and ingested although cannabilism was not observed in any of the field-collected solpugids. It may be that without the constraints of the test chamber, solpugids, well known for their rapid and erratic locomotor movements (Turner, 1916; CloudsleyThompson, 1961, 1977; Muma, 1967), may be too difficult to catch under natural conditions.

I want to point out that $86 \%$ of all solpugids encountered in the field were actively running across the surface in what seemed to be a random manner, rapidly tapping the ground in front of them with 
the palpi. This type of random cursorial searching behavior has been reported for a few other solpugid species (Muma, 1966) with the exception of termitophilous species which appear to exhibit more sedentary habits (Cloudsley-Thompson, 1961; Muma, 1967). In laboratory experiments, E. palpisetulosus exhibited well defined prey capture behavior as indicated by an analysis of video recordings. These solpugids responded quickly to tactile stimuli and locomotor activity of prey upon contact with their palpi or other legs. They appear capable of orienting toward substrate vibrations but will attack only if actual physical contact with the prey is achieved. I have not seen any evidence for careful stalking of prey by E. palpisetulosus as reported for one ammotrechid solpugid (Pocock, 1898) and several eremobatid species (Muma, 1966). When prey is encountered by $E$. palpisetulosus, initial contact is made with the palpi which are then used to pull the prey toward the chelicerae. The prey is then grasped firmly with the chelicerae. This is followed by a vertical motion of the movable cheliceral finger against the upper fondal teeth resulting in the fragmentation and grinding of prey tissues. In some cases, specific body parts of the prey such as the metathoracic legs (femurs) of acridids and gryllids, were severed and moved repeatedly through the cheliceral mill until most of the nonsclerotized tissue was ingested. Body parts such as wings, antennae, pro- and mesothoracic legs, and head capsules were frequently severed and discarded. In grinding the abdominal regions, especially in acridids, the intestinal tract was usually left intact and not ingested. The repeated grinding movements of the chelicerae were accompanied by a rhythmic pumping of the pharynx resulting in the transport of liquified food into the alimentary tract.

The ability of E. palpisetulosus to capture prey successfully increases significantly as a function of hunger level (Table 3 ). Solpugids deprived of food for $72 \mathrm{hr}$ exhibited a successful capture rate of 55\%. This dropped to $35 \%$ for those deprived of food for 48 $\mathrm{hr}(\mathrm{G}=18.3, \mathrm{p}<0.01$; Sokal and Rohlf, 1981). There was also a significant difference between capture rates for solpugids deprived of food for $24 \mathrm{vs} .48 \mathrm{hr}(\mathrm{G}=11.6, \mathrm{p}<0.01)$. There was no significant difference between animals deprived for $6 \mathrm{vs.} 24 \mathrm{hr}$. This contrasts sharply with the results obtained for the theraphosid spider, Dugesiella echina, from the same region, which exhibited a capture rate of $91 \%$ when deprived of food for $72 \mathrm{hr}$ (Punzo, 1989). 
Data on additional species (Ford, 1978; Nentwig, 1987; Punzo, 1991) also indicate a more efficient prey capture rate for wandering spiders as compared to the solpugid tested in these experiments. One possible explanation for this may be that many wandering spiders move readily between patches, but once reaching a suitable patch they frequently adopt a sit-and-wait ambush strategy (Nentwig, 1987). This may increase their level of responsiveness to potential prey that move into their awareness field (Curio, 1976) as compared to a predator that locates its prey primarily using vigorous, random and continued cursorial locomotor activity. Since these data are the first to be reported for a solpugid, it would be interesting to assess the capture rate for other solpugid species to see whether or not this difference is consistent across species.

The effects of food deprivation and predator size on ingestion time are shown in Table 4. A Model II ANOVA (Sokal and Rohlf, 1981) showed a significant overall effect of deprivation level $(\mathrm{F}=$ 151.4; $\mathrm{df}=3,44 ; \mathrm{p}<0.001)$ and predator size $(\mathrm{F}=88.6 ; \mathrm{df}=1$, $44 ; \mathrm{p}<0.001$ ) on ingestion time. Scheffe F-tests (Sokal and Rohlf, $1981)$ showed a significant difference in ingestion time between predator size classes at all levels of deprivation ( $p<0.01$ for 6,24 and $72 \mathrm{hr}$ of deprivation; $\mathrm{p}<0.05$ for $48 \mathrm{hr}$ ). Larger solpugids exhibited faster ingestion rates at all hunger levels. Regardless of predator size, increased hunger resulted in faster ingestion of food. This suggests that ingestion rate is not solely determined by mechanical limitations imposed by morphological features of the mouth parts and accessory feeding structures.

These experiments show that the level of food deprivation affects several parameters of feeding in E. palpisetulosus. Although hunger is generally associated with a collective series of internal messages related to caloric deficit (Dethier, 1982), it has proved difficult to observe and quantify (Punzo, 1989). The degree of hunger is influenced by the elapsed time between feeding bouts and has been shown to affect the degree of responsiveness of a predator toward potential prey (Curio, 1976). An increase in responsiveness to prey should lead to higher capture rates and faster ingestion time. The findings of this study support these predictions. 
Table 4. The effect of food deprivation (hr) and predator size on the amount of time (min) required for Eremobates palpisetulosus females to ingest a single cricket weighing $0.3 \pm 0.05 \mathrm{~g}$. Values represent means $( \pm$ S.D.) for 15 solpugids in each size class.

\begin{tabular}{ccc}
\hline Food deprivation & \multicolumn{2}{c}{ Mean ingestion time (min) } \\
\hline$(\mathrm{hr})$ & \multicolumn{2}{c}{ Predator size class (mean body length) } \\
& $9.3(0.6) \mathrm{mm}$ & $21.6(1.4) \mathrm{mm}$ \\
\hline 6 & $26.4(4.2)$ & $11.3(1.2)$ \\
24 & $15.6(3.2)$ & $7.3(0.4)$ \\
48 & $8.4(1.7)$ & $5.6(0.5)$ \\
72 & $11.2(2.7)$ & $4.1(0.7)$ \\
\hline
\end{tabular}

\section{ACKNOWLEDGEMENTS}

I thank James Bottrell and Thomas Punzo for assistance in the collection of solpugids in the field, Brian Garman, Dept. of Mathematics, for consultation on statistical analyses, Wayne Price for comments on an earlier draft of the manuscript, and Dan McCarty for permission to collect on private property. I also thank the University of Tampa for a Faculty Development Grant which made much of this work possible and anonymous reviewers for comments on an earlier draft of the manuscript.

\section{Literature Cited}

BANTA, B. H., AND P. J. MARER

1972. An attack by a solpugid on an iguanid lizard hatching. Br. J. Herpetol. 4: 266.

BolWIG, N.

1952. Observations on the behavior and mode of orientation of hunting Solifugae. J. Ent. Soc. S. Afr. 15: 239-240.

CLOUDSLEY-THOMPSON, J. L.

1961. Some aspects of the physiology and behavior of Galeodes arabs. Ent. exp. appl. 4: 257-263.

1977. Adaptational biology of Solifugae (Solpugida). Bull. Br. arachnol. Soc. 4: 61-71.

Curio, E.

1976. The Ethology of Predation. Springer Verlag, New York. 274 pp.

DETHIER, V. G.

1982. The contribution of insects to the study of motivation. In: Changing Concepts of the Nervous System (A. Morrison and P. Strick, eds.). Academic Press, New York. pp 445-455. 
FORD, M. J.

1978. Locomotor activity and the predatory strategy of the wolf spider Pardosa amentata (Clerck) (Lycosidae). Anim. Behav. 26: 31-35.

Muma, M. H.

1951. The arachnid order Solpugida in the United States. Bull. Am. Mus. Nat. Hist. 97: 34-141.

1966. Feeding behavior of North American Solpugida (Arachnida). Fla. Ent. 49: 199-216.

1967. Basic behavior of North American Solpugida. Fla. Ent. 50: 115-123. Nentwig, W.

1987. The prey of spiders. In: Ecophysiology of Spiders (W. Nentwig, ed.), Springer Verlag, New York. pp. 249-263.

Pocock, R. I.

1898. On nature and habits of Pliny's solpugs. Nature 57 (1487): 618-620. Punzo, F.

1974. An analysis of the stomach contents of the gecko, Coleonyx brevis. Copeia 1974 (3): 779-780.

1989. Effects of hunger on prey capture and ingestion in Dugesiella echina Chamberlin (Orthognatha, Theraphosidae). Bull. Br. arachnol. Soc. 8: 72-79.

1991. Field and laboratory observations on prey items taken by the wolf spider, Lycosa lenta Hentz (Araneae, Lycosidae). Bull. Br. arachnol. Soc. 8: 261-264.

1993. Intraspecific variation in response to temperature and moisture in Eremobates palpisetulosus Fichter (Solpugida, Eremobatidae). Bull. Br. arachnol. Soc. (in press).

Punzo, F., AND G. HuFF

1989. Comparative temperature and water relations and the effects of thermal acclimation on Tenebrio molitor and Tenebrio obscurus (Coleoptera: Tenebrionidae). Comp. Biochem. Physiol. 93A: 527-533.

SOKAL, R. R., AND F. J. ROHLF

1981. Biometry. 2nd ed., W. H. Freeman and Company, New York. 859 pp.

TiñKAM, E. R.

1948. Faunistic and ecological studies on the Orthoptera of the Big Bend Region of Trans Pecos Texas. Am. Midl. Nat. 40: 521-563.

TURNER, C. H.

1916. Notes on the feeding behavior and oviposition of a captive American false-spider (Eremobates formicaria Koch). J. Anim. Behav. 6: $160-168$.

WHARTON, R. A.

1987. Biology of the diurnal Metasolpuga picta (Kraepelin) (Solifugae, Solipugidae) compared with that of nocturnal species. J. Arachnol. 14: 363-383.

YounG, O. P.

1989. Predation by Pisaurina mira (Araneae, Pisauridae) on Lygus lineolaris (Heteroptera, Miradae) and other arthropods. J. Arachnol. 17: 43-48. 

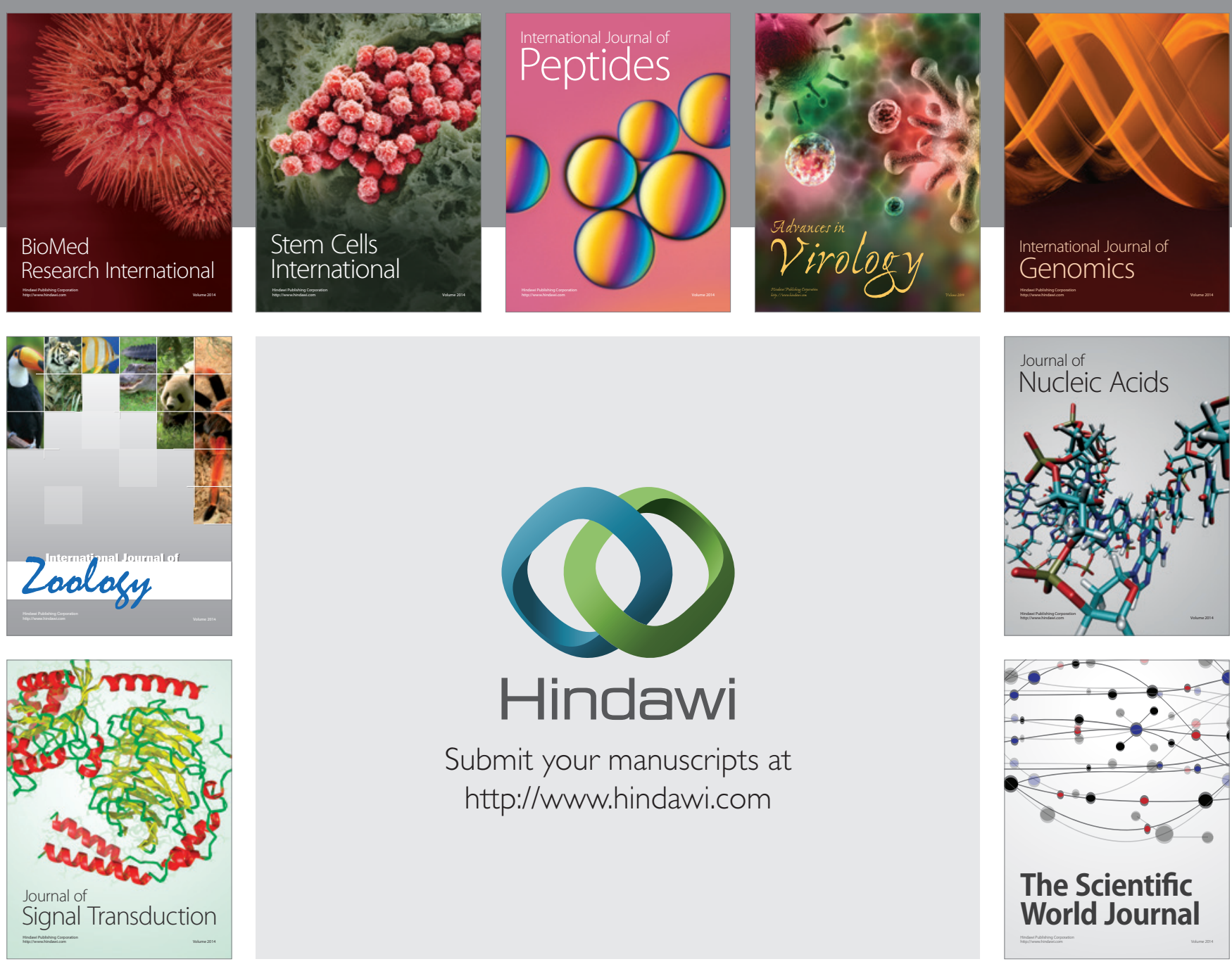

Submit your manuscripts at

http://www.hindawi.com
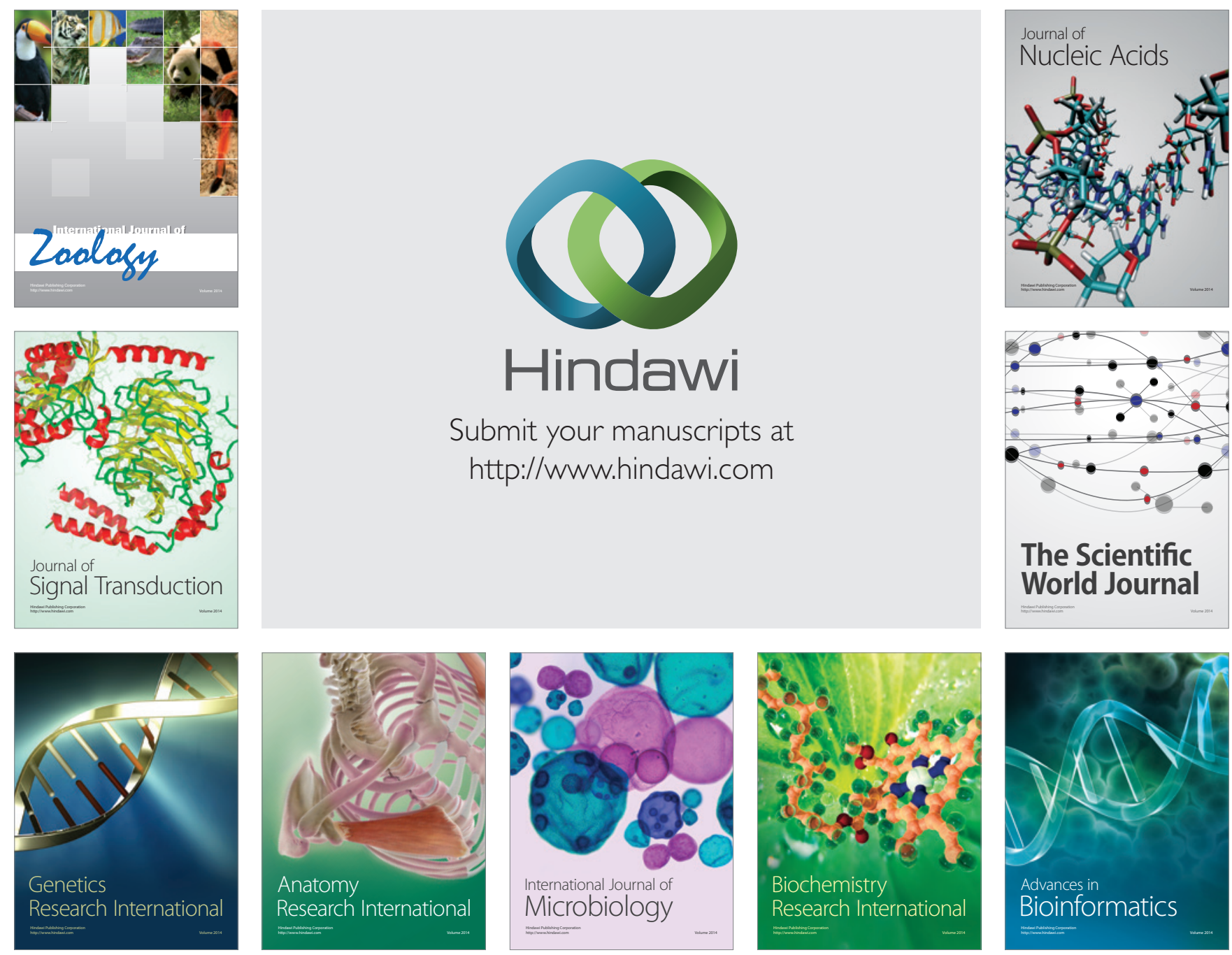

The Scientific World Journal
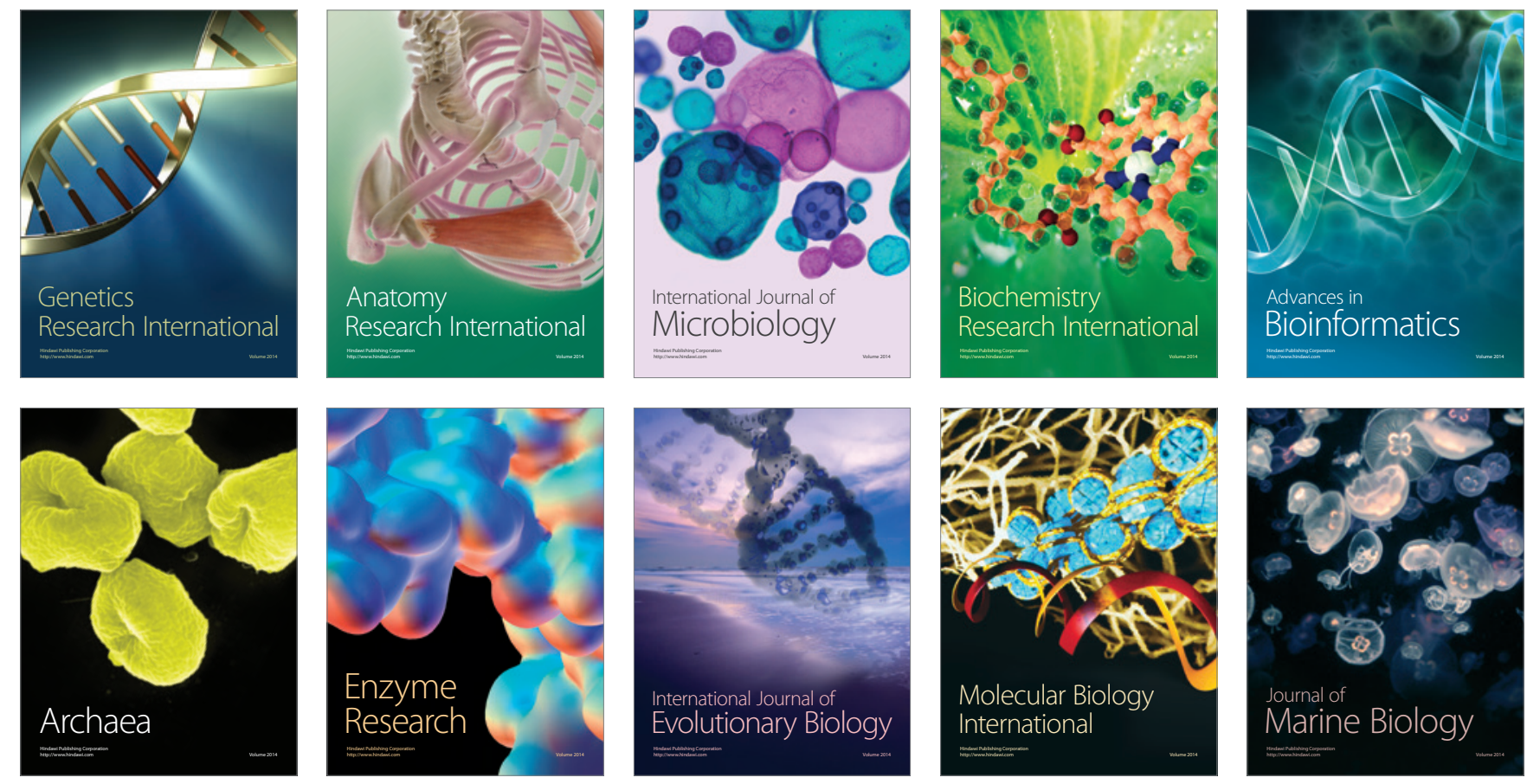